\title{
Cultural Dominance and Language Endangerment: The case of Efut in Gross River State, Nigeria
}

\author{
Margaret Mary Okon * \\ (University of Calabar, Nigeria) \\ Paulinus Noah ** \\ (University of Calabar, Nigeria)
}

\begin{abstract}
The Efut culture, and by extension language, seems to have been mortally threatened after their speakers' migration to Nigeria from Cameroun in the $16^{\text {th }}$ Century. The linguistic situation resulting in language shift was especially exacerbated in the last seven decades, largely due to the dominant cultural influence of Efik, Ibibio and English. The most ostensive vestige of the language manifests in the Ekpe 'Leopard' secret society songs, rituals and proverbs (performed by, and intelligible mostly to octogenarians). The Efut language sociolinguistic status is between post moribund and dead stage(s). This paper attempts, therefore, to $\mathrm{x}$-ray ways to revitalize and revive it. Two such revival strategies are the use of digital communication technology and Efut in Nollywood movies. Data for this work came mainly from songs, proverbs, interviews, wordlist and available historical literature. The prognosis for reviving Efut appears realistically poor, at present. However, with appropriate input and pragmatic will from all stakeholders, it would be hasty, uncharitable, to consign the language to irreversible extinction. This optimism is sustainable only if language engineers, policymakers and the Efut nation do not continue to sit on the fence.
\end{abstract}

Keywords: Efut, Balondo, language endangerment, cultural dominance, language engineers, reversing language shift

\section{Introduction}

Language and culture are very closely related, even as they may not be seen as two faces of the same coin. These concepts have occupied the attention of anthropologists, sociologists and other professionals for ages. If culture is seen by anthropologists to refer to

\footnotetext{
* Dr. Margaret Mary Okon: Professor, Department of Linguistics and Nigerian Languages, University of Calabar, Nigeria. Email: mmaokon@yahoo.com.

** Dr. Paulinus Noah: Department of Linguistics and Nigerian Languages, University of Calabar, Nigeria. Email: seemaekediong@gmail.com.
} 
all aspects of human life that are regulated by man as a member of natural society, then human language is evidently its most august component, possibly. Natural language can only thrive in human society and it is transmitted culturally. Though (the lower) animals also communicate, it is the possession and use of language that uniquely makes us human, enhancing our ability to maximize the utility resources, and potentials of our environment, space and the universe (for our sustenance and sustainable development of the world). If an unwritten language is not used by its native speakers, it stands the easy risk of being lost to language shift.

The Efut, a minority people living in Cross River State, Southern Nigeria, is one of the numerous Nigerian languages without robust speakers. It is a Bantoid, Benue Congo, Niger Congo language which exists mostly in name and geographical space without intergenerational transmission; having been pressured and suffocated by English, Efik and Ibibio. In view of the need to revive and maintain the world's languages for sustainable development, this paper discusses Efut's precarious situation and proffers strategies for reviving it.

We feel there is a palpable void in language revitalization effort with regard to Efut. No positive effort has been undertaken in recent decades towards reanimating the language, hence, our current research action. The use of one's ethnic language is a fundamental human right that must be protected.

\subsection{Efut history and hierarchical structure}

According to the Efut people, the Efut in Nigeria, who are of a Bantu (Bantoid) origin, are related to the Bafut, Idombi and Oroko, through Badondo ( Balondo) and Basanga $(\sim \text { Batanga })^{\mathbb{1}}$. The Efut founding fathers are: Nabunda, Na Ukem, Na Mkpara, Ebuka, Atu Iyoka, Ifakama and Ifundu ( Ibundu) of the tribe of Badondo (Balondo). The first Efut people left Cameroon during the Batanga war through Usakedet and arrived in Ikang, then Esighi (in Isu Ekom) before reaching Edibe-Edibe in Calabar. After a while, they expanded their land acquisition to Odukpani, while Atu and Ebuka remained in Calabar forming Efut Abua and Efut Ekondo. The core Efut settlement in Odukpani is Efut Ibonda ${ }^{2}$. Today the

\footnotetext{
(1) We are indebted to Dr. Ivor Miller for making his rich data and resources on Efut available to us as well as being part of our exploratory contacts in Efut land. We thank His Royal Highness, Muri Nyong Etim Ekpo, the Clan Head of Efut Ekanem Ama for his invaluable assistance to source for an informant. Our huge gratitude is due to Ndabo Ekuke Daniel Ita for supplying the much needed language data on Efut. Our appreciation is also due to Dr. Bassey Bassey of the Department of Geography and Environmental Science, University of Calabar, for assisting us with the map of Efut-speaking Local Government Areas in Cross River State (www.geospatialinks.com.ng).

(2) This historical sketch is from The 2003 Efut Ibonda Memorandum on the Recognition of Clans in the Cross River State. Ibibio is not indicated as a specific territory in the map despite its superior numerical strength in the five Efut-speaking LGAs and its consequent cultural influence because it is considered to be from a different state of Nigeria (Akwa Ibom State).
} 
Efut are found mostly in Akpabuyo, Odukpani, Bakassi, Calabar South and Calabar Municipality (as shown in Map 1 below), with a claim to the ancestry of these Local Government Areas (LGAs).

The Efut exercise control in their domains of jurisdiction through a Councilor, the Village Head, Clan Head, and Paramount Ruler or Patriarch. The hierarchical structure is as follows:

$\begin{array}{ll}\text { Musumba } & \text { Honorary chieftaincy title } \\ \text { Mokafa } & \text { Chief or (traditional) Councilor } \\ \text { Mbonka( Mbonga) } & \text { Woman Leader } \\ \text { Ndabo } & \text { Village Head } \\ \text { Muri } & \text { Clan Head } \\ \text { Muri Munene } & \text { Paramount Ruler/Patriarch }\end{array}$

However, the Balondo people, which is the Cameroon version of Efut (or Efuri as some call it in Cameroon) comprises: Balondo Ba-Nanga (or Balondo Na-Menge) and Balondo Ba Liko of Ndian Division in Kumba in the South West Province. Historically, the Balondo have two versions of origin: (a) that they migrated from Congo - as part of the Bantu Shift, (b) that they are of the South Eastern Nigerian origin (most likely Old Calabar). The South East Nigeria Theory of origin is discredited by some scholars such as Carney (1936:11), "some suffering from a superiority complex state that their place of origin was Nigeria. This might be true of part of the stock, but certainly not for all, the Bantu element is too strong". Traditionally, the Efut (Balondo) are seafarers (engaged in fishing, having been blessed by the abundance of sea and creeks in their vicinity), hunters (engendered by natural surrounding forests) and craftsmen (in wooden household utensils, mats and baskets).

\subsection{Efut and their immediate neighbours}

The immediate neighbours of the Efut in Cross River State are principally Efik, Ejagham (or Qua) and Ibibio. It seems the impact of the Ibibio and Efik languages on Efut has accelerated the decline of the Efut language and culture. Though the Efut language is distinguishable from both Ibibio and Efik, according to the Efut Combined Assembly (2003:48), "the so-called Efik that all of us speak is not even the original language of the Efik". The Efut Combined Assembly seemed to have reached this conclusion partly based on Oku's (1989:xiv) assertion that:

The period of sojourn among the Ibibio left everlasting imprint upon the Efiks. Only the quarrel and their subsequent eviction saved them (the Efiks) from imminent absorption. During that sojourn the Efiks acquired their modern ethnic name, Efik (an Ibibio word meaning "oppression") and incorporated many Ibibio words into their language to the fantastic extent of assimilation. The aborigine Efik language has almost fallen into oblivion, but fortunately, a lot of it remains preserved in Efik personal names. 
The Efut Combined Assembly (2003:49) continues, "from historical facts, the Ibibios are still where they were and it is the Efiks who moved on carrying along with them a language based on Ibibio. When the Efiks were received by the Efut people at Creek Town this Ibibio language became a common language of communication".

The weight of these linguistically and geographically close neighbours may be part of the burden militating against the sustenance of Efut. This closeness has engendered intermarriages between the three peoples, with devastating consequences for the Efut ethnolinguistic profile and viability. For example, almost all our exploratory interactions in the Efut capital town, Anantigham were done in Ibibio despite our conscious efforts to elicit language data in Efut. These include, activities in the Anantigha Beach market, where the leading author made purchases.

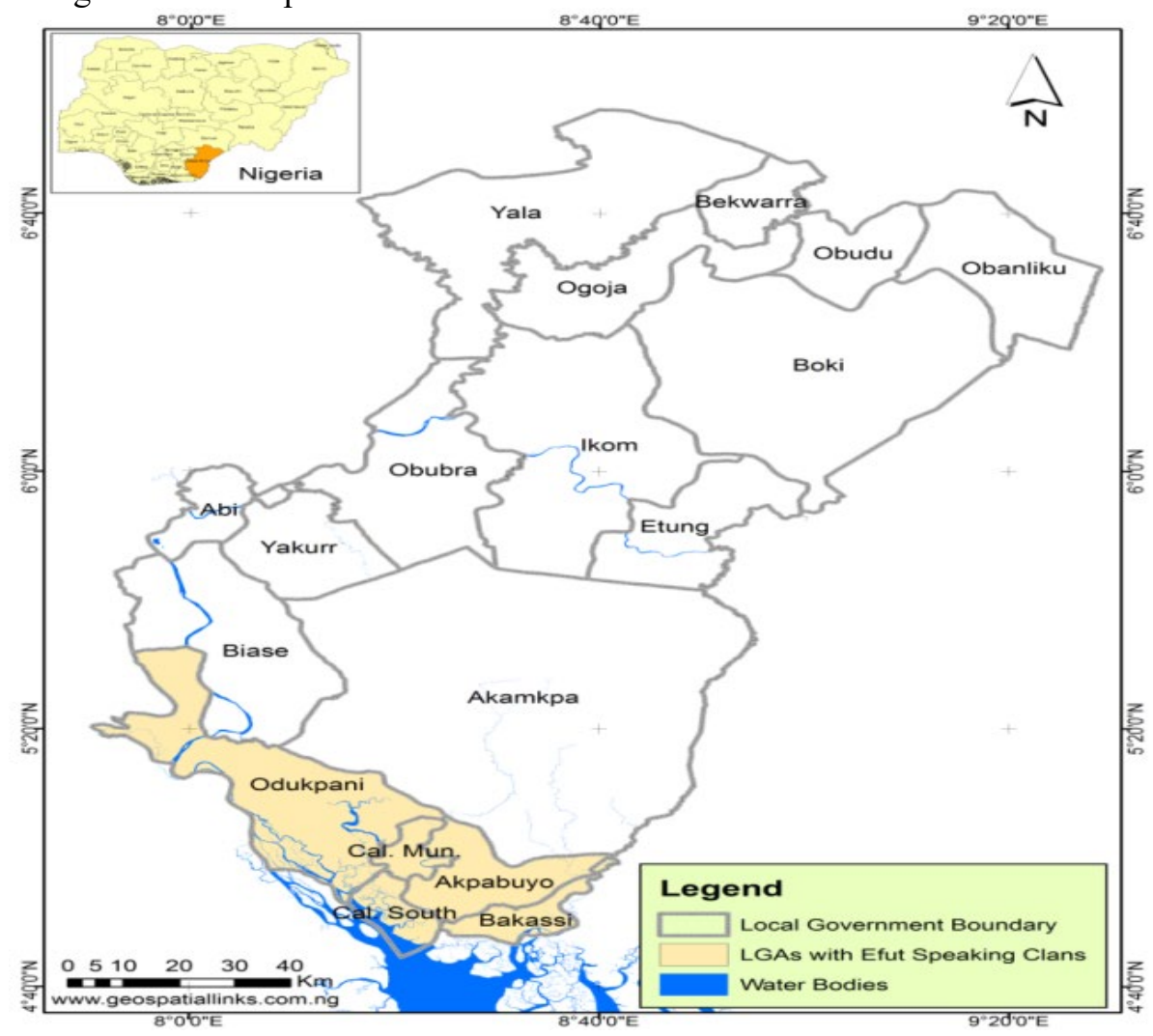

Map 1. Efut-speaking Local Government Areas in Cross River State, Nigeria

\section{Risk factors in language endangerment and language death}

Language endangerment and death do not occur as a 'bang' phenomenon or act. They follow a gradient of factors, a process of vitality, sickness and death, after a symptomatic 
phase, if no pragmatic procedures are appropriately effected. Endangerment is a matter of degrees. In most cases, a once vibrant language would pass through some of these stages before extinction: deprived, threatened (and/or potentially endangered, mortally endangered and/or threatened), moribund and eventual extinction. In other words, the decline of a language from its viable phase usually follows the facets of where the language is: used by fewer speakers in specified domains; disadvantaged culturally, educationally, socioeconomically; spoken by few children; spoken by a handful of adults; spoken by a handful of old people and no longer transmitted to later generations; left with no speakers (but possibly still remains in recorded or written form. cf. Fishman, 1991). For now let us examine some of these risk factors in relation to the Efut language situation in particular, and other Nigerian languages in general.

To be sure, since living languages are used by human beings, any factor which threatens man's existence also endangers man's language. While some factors, especially natural factors (such as war, government policy, insurgency, oil spills, tsunami, epidemic disease, volcano, earthquake) can cause (near) immediate language shift, other factors such as cultural and economic usually result in gradual language endangerment and death. Some of these are discussed in subsequent sections below.

\subsection{Linguistic and cultural dominance}

While it is possible to discuss linguistic and cultural factors in language endangerment as separate, we choose to integrate them due to their mutual dependence. We shall view linguistic dominance as a phenomenon where a powerful language lords over, suppresses and distresses a weak one. The dominant language can be either foreign or indigenous. A powerful or weak language is viewed in relative and not absolute terms, without any logical or inherent attachment to numerical strength or paucity (cf. Essien, 1990; Noah, 1999). For example, during the colonial era in Nigeria, the Efik language with a population of about 26,300 people (Forde \& Jones, 1950) served as the literary dialect of much of the Ibibio-speaking area with a population of 800,000 (Forde \& Jones, 1950), as a language of administration, education and religion.

The Efut language has been depressed, challenged and suffocated not only by English but by Efik and Ibibio, both in her Cameroon homeland and in Nigeria. Large number of Efik and Ibibio speakers not only live, work in Balondo but also engage in trans-border trade (from Ifiayong and Oron in Akwa Ibom State and Calabar in Cross River State). In fact, in the 1930s, the population of Ibibio speakers in the adjourning areas of Kumba and Victoria was said to be in the ratio of 3 to 1 with the indigenous people in favour of Ibibio, according to Yenda (2009). Part of the consequences of this endogenous and exogenous relationship has created a near one-sided borrowing of lexical items from English, Efik, 
Ibibio, at least, into Efut making the recipient the poorer, ethnolinguistically ${ }^{(1)}$.

Cultural dominance may have little or no direct effect on the physical safety of the affected people. A particular community may lose its cultural vitality in response to internal or external factors or pressures, with the effect most noticeable in the spheres of language, religion and social value. In the end, there would be cultural assimilation and language is often the critical bastion of that dominance. When one culture is influenced by a more powerful culture, the language of the less dominant culture begins to decline and eventually goes into extinction. The usual 'progression' is for the weak culture to lose its indigenous flavour, tone and character and assimilate new mores in religion, communication, education, arts and business from the major language.

Cultural dominance is not always caused by the physical threats to the safety of the assimilated people. For example, the Efut people of Cross River State still largely inhabit their ancestral territories. However, the Efut language continues to suffer in a steep decline. The large influx of immigrant population in the Efut territory in the Calabar South LGA may, partially but not sufficiently, induces the spate of cultural assimilation. In any case, cultural assimilation has three common stages: (a) pressure to speak the dominant language. This pressure may be 'bottom up' or 'top down': from fashionable trends, peer group influences or from political, social or economic influence. Sometimes the source of the pressure may not be fully understood. (b) the second stage is characterised by gradual bilingualism in the old (mother tongue) and the new (dominant language), accompanied by a decline in the use of the former. (c) eventually, there is a lack of interest, proficiency and pride in the use of the mother tongue, especially in the emerging generations. In a matter of decades, this bilingualism slips to self-conscious semi-bilingualism, then to monolingualism, which prepares the mother tongue for possible extinction (Crystal, 1992, 2000).

This is, indeed, part of the process that has been translated to the current post moribund (near extinction) status of Efut. The cultural influence of Efik, Ibibio and English, the demographic advantage of Ibibio-speaking cluster of speech forms (Ibibio, Anang and Oron) in the Efut territorial space have combined to whittle down the viability and active use of Efut. In fact, in the Efut aboriginal homeland (Cameroon, where it is called Londo/Balondo), this cultural influence is equally pronounced, as confirmed by Kuperus (1985:7), "the geographical position of the Balondo area, just to the East of the Cross River Delta, also explains the rather large proportion of borrowing from Efik, Ibibio".

No doubt, language has a stupendous impact on the psychology and culture of its users, especially the case of L2 or non-mother tongue, other than in situations of linguistic

\footnotetext{
(1) Some lexical items loaned from Efik and Ibibio into Efut are supplied in a subsequent section of this work entitled "Borrowing" (2.2.3).
} 
imperialism. As has been affirmed in many sources, this tremendous impact that language exerts on the attitude of users is surreptitious but potently pernicious (cf. Noah, 1999, 2003). This makes it all the more easy, natural for users (of foreign language) to either overlook or underestimate such impact, ordinarily. For example, according to Kuperus (1985:7), "the Efik language has a certain social status, Efik proverbs being quoted by some Londo speakers in local public meetings". This situation spells a definite and sometimes irreparable slip into acculturation, with all the attendant impact on mother culture, mother tongue. Perhaps this was what Lambert (1963) had in mind, when he stated that "from this point, one anticipates that if the learner is appropriately oriented, he may find by learning another group's language he has made the crucial steps of becoming an acculturated part of a second linguistic-cultural community" ${ }^{(1)}$.

Should we, therefore, not learn languages other than our mother tongue? Of course, that is not our point. Indeed, it is very useful to learn languages, as there are myriad advantages of bilingualism or multilingualism, by extension biculturalism or multiculturalism. The problem arises, however, when acquiring a new language and culture impinges distractively on our indigenous language and culture or induces an uncomfortable disposition, feeling in one retaining membership of one's original culture. This leads to eventual apathy, disuse and possible death of that culture and language. This is the situation with the Efut culture and language. At present, almost no indigenous Nigerian speaks Efut (none that the current researchers could trace, or any recent scholar that we have information of). Almost all sources report that Efut is a dead language (cf. Akak, 1998; Mensah \& Offiong, 2004; Ndimele, 2012) ${ }^{2}$.

Nonetheless, vestiges of the language, culture, survive in libation rituals and in Ekpe (secret society) songs, but which continue to be influenced by those of the neighbouring cultures (Efik, Ibibio and Ejagham/Qua). The regular Nyoro Ekpe (Leopard Dance Festival/Competition) attest to the vibrancy of this aspect of the Efut culture till date. However, as is also eloquently summarised by Nebengu (1990:102) "on the whole, the

\footnotetext{
(1) In fact, even with his Negritude ideology of self-assertion and African authenticity, Leopold Sedar Senghor still perceived African personality via the index of Greek ethos; as models to be indulged and emulated by (black) Africans, after rationalising that the ancestors of Ancient Greece were aboriginal Africans (from Egypt, from the South, and was Black, cf. Nnadi, 1982:14).

(2) The situation in Cross River (Nigeria) is not remedied by the lack of adequate personnel and programmes dedicated to language documentation and revitalization. Except the University of Uyo (at the postgraduate level), almost no Nigerian university concentrates on language documentation. The few language documentation projects are in Northern Nigeria e.g Nigeria Bible Translation Trust (Jos), Jos Linguistic Circle, Plateau Language Survey Project, Southern Bauchi Language Survey. However, there are the Kay Williamson Educational Foundation and the University of Uyo Lower Cross Languages Project, and recently, the Nigerian Languages Project. The tremendous effort of Miller in documenting Ekpe songs and establishing their diasporic links is very highly commendable (cf. Miller, 2009, 2012).
} 
Balondo society, culture and traditional values have to a large extent been acculturated". Furthermore, Nebengu (1990:6) avers that "an ancient town of the Balondo people, the Ikundu Town has been obliterated and assimilated into a neighbouring community in Cameroon.

\subsection{Other factors}

While cultural dominance is the thrust of our work and the key factor that has endangered Efut, other factors such as intermarriage, code-mixing, globalization and borrowing are also complicit.

\subsubsection{Intermarriage}

Over the years, Efut indigenes have married outside their ethnic groups, notably Efik, Ibibio and Ejagham. These otherwise healthy unions have been one of the greatest factors that have eroded Efut ethnolinguistic and ethnocultural roots. With the weak numerical, political, economic base and perceived low prestige of Efut, offspring of these marriages shift their linguistic and cultural royalties to Efik and Ibibio, most often. Originally, our chief informant for the exploratory fieldwork is a Balondo Cameroonian, who has however lived in Nigeria for much of his adult life, largely due to his maternal lineage in Cross River State. His wife is Efik and all his children speak Efik. None of the indigenous Efik staff spoke Efut among themselves during the course of our visits. Our enquiry revealed that most of them are offsprings of inter-ethnic marriage, where some of their parents are invariably Ibibio, Efik and sometimes Ejagham (Qua). The situation exacerbates the non-intergenerational transmission of the Efut language and portends great endangerment. Also, we observed in the course of our fieldtrip that the indigenous students of the University of Calabar and the Cross River State University of Technology (Calabar), which are the indigenous linguistic locale of Efut do not speak Efut as they are equally offsprings of intermarriage and are highly prone to code-mixing and language shift.

\subsubsection{Code-mixing}

Code-mixing is very common in a multilingual state like Cross River and most other Nigerian domains. Linguistic, psychological and social factors underlie and promote code-mixing in language contact situations. Though a natural language phenomenon, it is one of the ways that dominant languages put their weight on the frail and bent neck of endangered ones. Far from always being a communication bridge, it can actually become a bar towards endangered language regeneration (cf. Mougeon \& Beniak, 1991; McConvell \& Florey, 2005). Our principal informant code-mixed (Efut-Ibibio-Efik and Efut-English) a lot during our field work sessions.

\subsubsection{Borrowing}

Borrowing is a natural linguistic process by which words are copied or loaned from one language to another. This can be caused by lexical paucity or for social (prestige) reasons. 
Extensive borrowing can sometimes influence the phonotactics of a recipient language. Borrowing would continue to be a positive language phenomenon if it is always symbiotic. But because it is more often osmotic than mutual, weak languages are left without power. Decades of unidirectional borrowing from Efik and Ibibio has endangered the viability of Efut/Balondo. Consider a few examples:

$\begin{array}{llll}\text { Ibibio } & \text { Efik } & \text { Efut (Balondo) } & \text { Gloss } \\ \text { aduma } & \text { aboma } & \text { aboma } & \text { 'thunder' } \\ \text { afanekoñ } & \text { afanikoñ } & \text { afanikoñ } & \text { 'trouble' } \\ \text { akañkañ } & \text { akañkañ } & \text { akamkañ } & \text { 'sword' } \\ \text { akpara } & \text { akpara } & \text { akpala } & \text { 'prostitute' } \\ \text { ekpat } & \text { ekpat } & \text { ekpa } & \text { 'bag' } \\ \text { ekpo } & \text { ekpo } & \text { ekpo } & \text { '(ekpo) masquerade' }\end{array}$

\section{The endangered language situation in Cross River State and Nigeria}

Language endangerment can be essayed from the point of view of users, uses or functions, at least. While some languages are shrinking in Nigeria in numerical strength and functional loads (like Ejagham in Cross River State, Izza in Bayelsa State, Chibok in Borno State), others are expanding (like English, Arabic, Nigerian Pidgin, Igbo, Yoruba and Hausa). Though such linguistic expansion could serve to challenge users of endangered languages to gird their loins, find ways to revive, preserve their culture and identity via robust use of their mother tongue, this is hardly the case in Nigeria, at least in the Cross River State area.

According to Okwudishu (1997:123), "an endangered community is one in which any of these four elements is threatened: (1) a common territory, (2) a common language or dialect, (3) a common custom, (4) a common descent". However, we suggest that these factors are a bit too idealistic in our contemporary society.

A number of studies have been documented on aspects of language endangerment in Nigeria. We examine a few to distill a common thread and attempt to fill some gaps. Faraclas (1989) reports that Iyoniyong (Bakpinka), Kiong (Okoyong) and Odot (Odut) are faced with extinction. Of these three, Kiong is the most threatened, where only few adults speak and there is no intergenerational transmission (cf. Noah, 1990, 2004; Okon, 2004; Okon \& Noah, 2009). Okwudishu (1997) again states that according to CEL, Gombe and Bauchi States in Northern Nigeria have lost about 25 of their estimated 90 languages. Other states that are equally assaulted by this phenomenon are Plateau, Kebbi, Sokoto, Kaduna, Kogi, Niger and Nassarawa, due largely to the influence of Hausa (and the Nigerian Pidgin to a less extent). In fact, Nassarawa State alone is said to have lost 20 of its local languages. In the view of Haruna (2009), most minority languages in the linguistically complex axis of 
Northeastern Nigeria will be scourged out by the tip of the $21^{\text {st }}$ century. Udosen (2009) lists the human, religious and political challenges associated with language documentation in North East Nigeria, from the Borno State dimension ${ }^{\circledR}$. Ugot \& Ogar (2014) avers that many languages in Cross River State, Akam for example, are threatened by cultural assimilation. Crozier \& Blench (1992) mention that Kiong, Bakpinka, Odut in Cross River State are facing extinction, while Korop is retreating and Qua is being gradually assimilated by Efik.

The above submission is a near accurate diagnosis of the Efut language situation. In fact, the Efut situation is more calamitous. This is a very sad scenario. We can no longer sit and watch these languages die out one after the other.

By many known accounts (cf. Noah, 1990, 2004; Ugot \& Ogar, 2014), Efut is a mortally moribund language. Some scholars conclude it is actually extinct (Akak, 1998; Mensah \& Offiong, 2004; Ndimele, 2012). The existence of Efut, even as a moribund or endangered language is not alluded to or mentioned in most language documents pertaining to the Cross River State and/or the Niger Delta Region and Nigeria in the last five decades or so (c.f. Essien, 1982, 1979, 1987, 1990; Sterk, 1979; Faraclas, 1989; Hansford, BendorSamuel \& Standford, 1976; Udoh \& Okon, 2008; Lewis, 2009; Simmons \& Finnig 2017; Williamson \& Blench, 2000). Ndimele (2012) states that the "Efut language is extinct. The last speaker of Usakedet (the language of the Efut people) died in 2001 (cf. Mensah \& Offiong, 2004:9)". The variety of Efut spoken in Usakedet (Usakade) is called Isangele or Usaghade in Cameroon, which Connell (1991) classifies as a Lower Cross language. The Usakede, as Connell (1991:10) affirms, "generally understand and can speak Efik, and can understand Ibibio, though the reverse is not true".

Finding a fluent indigenous Nigerian speaker of Efut in Calabar is similar to finding a needle in a haystack. After several visits to the Temporary Palace of the Muri Munene-Elect, we eventually got help from the Secretary General of the Efut Combined Assembly, His Highness Ndabo Godwin Bassey and the Efut Youth Leader, Etubom Essien Asuquo Essien. Despite the effort of the Efut Secretary General and the Youth Leader to get us a reliable Efut informant, it was the 'Midas touch' from His Royal Highness, Muri Nyong Etim Ekpo, that eventually materialised our dream of getting an informant.

Language attitude among the Efut community at present is varied and asymmetrical, from our brief exploratory interactions. There is a strong passion by the middle-aged and elderly population for Efut language revival, preservation and cultural transmission. In fact, up till 2012, before the lockdown of the Traditional Palace of the Paramount Ruler of Efut on Palace Road in Anantigha by the Cross River State Government, there used to be primer

\footnotetext{
(1) Our chief informant for the exploratory fieldwork is originally a Balondo Cameroonian, who has, however, lived in Nigeria for much of his adult life, due largely to his maternal lineage in Cross River State.
} 
lessons in Efut history, culture and songs. These sessions have ceased due to political intrigues surrounding the leadership of the Efut Kingdom, according to our source. Sadly, on our last two visits to the Temporary Palace of the Muri Munene-Elect, we were witnesses to the business of the Efut Assembly being conducted in Efik, including Christian religious songs in English, Efik and Ibibio.

Thus far, we have had three sessions of data collection from our principal informant Ndabo Ekuke Daniel Ita Odionka (59), a retired Naval Officer who lives in Akpabuyo, one of the Efut-speaking local government areas. We have scheduled more sessions that would enable us make a formal linguistic analysis on aspects of Efut. Here below is an extract of Efut words and glosses in English:

$\begin{array}{llllll}\text { myoko } & \text { [joko] } & \text { 'one' } & \text { lito } & {[\text { lito] }} & \text { 'ear' } \\ \text { weba } & \text { [wèbá] } & \text { 'two' } & \text { muleli } & \text { [muleli] } & \text { 'food' } \\ \text { weyau } & \text { [wèyèù] } & \text { 'three' } & \text { ikpa } & \text { [ikpa] } & \text { 'salt' } \\ \text { weni } & \text { [wèni] } & \text { 'four' } & \text { danga } & \text { [dàngâ] } & \text { 'sleep' } \\ \text { weta } & {[\text { w ètá] }} & \text { 'five' } & \text { muya } & \text { [muya] } & \text { 'fire' } \\ \text { liwo } & {[\text { liwo] }} & \text { 'neck' } & \text { igbe } & \text { [igbe] } & \text { 'sun' }\end{array}$

Part of the fact and materials from our exploratory fieldwork that indicate the endangered situation of the Efut language is seen in the prodigious borrowing of basic lexical items from its sociolinguistically powerful neighbours (Ibibio, Efik). Such items include equivalents for 'thunder', 'trouble', 'sword', 'prostitute', 'bag' (cf. 2.2.3). Others are: $m b \wedge k$ 'story', okpoho 'money', ayo 'moonlight dance' and bot 'create'. Efut survives literally on its rich material cultural heritage. However, constant borrowing of basic cultural concepts like ekpe 'leopard', ayo 'moonlight dance' and ekpo 'masquerade' seriously threatens its survival and lets it slides it fast down its extinction path. When a heritage language abandons its linguistic repertoire in favour of its powerful linguistic neighbours (Efut word for 'leopard' $m g b e$ abandoned for Ibibio-Efik ekpe for example), its risk factor of endangerment increases.

\section{The need to preserve Efut and other endangered languages}

The world is a multinational, multicultural and multilingual one. We guess this trend of cultural pluralism will endure for the foreseeable future, despite covert and overt intrigues of globalization towards a universal western monoculture. The myth of 'national unity' built on a monolinguistic culture has been botched, deleted by some outrageous and scaring events, conflagrations, in largely monolingual nations like Burundi, Cambodia, Rwanda and Vietnam. In some of these cases, the killings were tantamount to holocaust. Partly because of the above, global or national monolingualism is no guarantee to peace and unity. Reviving and preserving Efut will enhance confidence in the people to share in the task of 
Cultural Dominance and Language Endangerment: The case of Efut in Cross River State, Nigeria

fostering peace and unity in Cross River State.

The conservative argument, principally Eurocentric, of multilingualism being a threat to national unity, seems, on close scrutiny, to be intellectually and scientifically dubious. Rather than be a drag, language is part of the wealth base that multilingual states can derive value to contribute to their overall national productivity; since language can have positive influence on the economy. This can be fleshed from the spheres of arts, tourism and local industries, where diversity is promoted and individuals invest to promote, project their identity. Interestingly, the Cross River State is, undeniably, the Nigerian tourist destination (one can speculate for West Africa), and Calabar (the State capital) has strong diasporic links with, and appeal to the Americas and the Caribbean. This link and appeal are incomplete without a strong Efut cultural, hence linguistic revival, especially bearing in mind the ancestral origin of Ekpe - a core component of the famous Annual Calabar Carnival (see Miller, 2009). This Carnival is a major foreign exchange earner for the state because of the huge number of foreigners that attend it and buy cultural items of arts. This is part of the economic benefit of language diversity, multilingualism, reversing the Efut language shift.

More than this, multilingualism expands people's view of the world. Appreciating other peoples' language predisposes one to understand other peoples' ethos, culture and welt-anschauung. To a great extent, a multilingual mind, and brain is a culturally more informed mind and brain. Our modern world would be the worse for it, if it is deprived of the enormous potentialities that cross-fertilization of ideas, perception and thought offers us via cultural and linguistic pluralism. Efut has something unique to contribute to the universal worldview.

We need to revive and preserve Efut and other like extremely moribund languages partly to enhance the sustenance of the universal ecosystem. A similar awareness and vigour with which biological diversity is pursued in order to sustain our ecosystem need to be applied to linguistic diversity. A non-atomistic view of ecology must emphasize that any threat or injury to any component of the ecosystem, be it biological or cultural, portends extortionate, unimaginable consequences for the entire system. Because evolution thrives in diversity, the greater our diversity (cultural or biological), the greater our chances of genetic adaptation and survival. In the view of Crystal (2000). The Efut language/culture is an important member of our ecosystem; losing it will leave a huge void in our cultural ecology.

Reasoning on a similar plain, Dixon (1997:116) submits that "language loss is the most precious loss of human resource. Only by studying the varied possibilities across all languages (our emphasis) can we gain a general picture of the nature of human brain as it relates to human activity". We cannot conjecture the 'wealth of riches' of Efut if we lose 
the key that custodies it, nor can we access the universal brain in the absence of mortally endangered languages like Efut.

Languages are the pedigree of communities, nations and the repositories of history in the sense of ancestry, descent and the fact that it takes language to archive history. With a loss of language goes much of its history. Edwards \& Sienkewicz (1990:15) expands this view thus: "we are vessels of speech, we are the repositories which harbour secrets many centuries old... we are the memory of mankind; by the spoken word, we bring to life the deeds and exploits of kings for younger generations". If we watch and allow endangered languages to go extinct, what shall we transmit to the generations yet unborn? Which is why the Nigerian Conservation Foundation (NCF) is equally concerned about our duty to transmit our cultural heritage to the next generation. The NCF (in Okwudishu, 1997:124) highlights the point thus:

Wildife is not only an economic resource; it is also a national heritage that has pervasive influence on our religious beliefs, folklore and culture. The nation and indeed the world, suffers a cultural loss whenever any species are exterminated. We, the present generation, have a moral duty to preserve this heritage for the enjoyment and education of our children and future generation.

\section{Strategies for reviving Efut}

The success stories of language revitalization all over the world and the enthusiasm of Efut adult indigenes give us hope that adapting some of the strategies used elsewhere and devising new ones can put back zest in the life cycle of Efut. Among the strategies to be adapted, some of those proposed by Fishman (2000) and Tsunoda (2006) seem quite germane for our present task. We will incorporate them into others that we have devised as shown below.

\subsection{Documentation}

Apart from the negative attitude of language owners, it is easier to irretrievably lose an unwritten language than a written one. Hence, our first strategy is to document the Efut language. To the best of our knowledge, Efut has no recognized orthography, therefore our first step towards its resuscitation would be to devise a provisional orthography; to be followed by the promotion of a general literary culture. This will help preserve not only the language but other aspects of the Efut cultural heritage: stories, exploits, songs, ceremonies, etc.

\subsection{Use of films}

The Nollywood industry in Nigeria is rooted in indigenous culture. The film strategy has the potentiality to arrest people's attention and convey the desired instructive, pedagogical, patriotic message to Efut indigenes and exogenous enthusiasts. The introduction of Efut films would stimulate the mind and spark interest in Efut cultural revival. This will help 
preserve and transmit important facets of the Efut cultural, philosophical, social and religious life to the outside world, the Americas and the Caribbeans especially.

\subsection{Prioritization of Efut use in home and public domains}

The Efut Combined Assembly should encourage and reward the active use of the Efut language both in the domestic and public domains. The Assembly should strive towards and insist on a compulsory but gradual use of the Efut language in Efut traditional, official functions in the nearest future. Though language policies by the government are more often dictated by non-linguistic factors such as economic and sociopolitical considerations, linguistics heritage, resources can also be harnessed into economic capital with a more inclusive language policy that recognizes the rights of the language minority.

\subsection{Use of social network}

The use of the digital media could be an effective strategy in reviving Efut, as it has been done in other climes. The use of WhatsApp, Facebook Groups dedicated for Efut speakers can re-kindle interest in the use of the language by Efut youths, who constitute the highest users of these social media. This would also help to attract the interest of Efut people in the diaspora to inject fresh ideas, and bring new perspectives on the revival of the culture and language.

\subsection{Attitudinal re-orientation}

If Efut is to be successfully revived and maintained, there has to be an aggressive attitudinal re-orientation to make the Efut appreciate their descent language and culture, as an index of their natural identity. There is a need to preach patriotism, ethnic identity, self-pride and authenticity to them; remind them that the English language was once considered a 'vulgar tongue' in classical times; and, that the Efik or Ibibio language may not be able to express the weight of their cultural heritage adequately. This re-orientation must not stop at the ideology of ethnolinguistic authenticity or identity. More importantly, it has to be sustained with a continuing ethnohumanistic, ethno-religious, and ethnocultural constellation of beliefs, behaviour and attitudes (Fishman, 2000).

\subsection{Use of successful LRS stories}

As a follow up on the need to develop a positive and patriotic attitude towards the Efut language, documented stories of successful language reversal shift elsewhere could stoke Efut indigenes to adopt the "yes we can" mentality. Stories of the resuscitation of the following languages, among others, could give some motivation, inspiration and challenge Efut people to wake up, join hands to revive the language:

1) Kaurna, an aboriginal Australian language whose last speaker died in the 1930s is now alive with many speakers;

2) Cornish, a Celtic language in England that was extinct 100 years ago has over 550 speakers after revitalization (cf. Eisenlohr, 2004; Ellis, 1985); 
3) Maori that was declared extinct some decades ago is now alive with over 60,000 speakers (Tsunoda, 2006).

\section{Conclusion}

In normal circumstances, language endangerment and death follow an atrophying gradient. They hardly occur as an accident. The mass exodus of the Efut people from their Cameroonian homeland during the Batanga war, distractive codemixing and bilingualism, intermarriage, numerical and political disadvantage, absence of Efut orthography, close geographic proximity to neighbours with similar languages (Efik, Ejagham and Ibibio), limited usage domain, poor language attitude, among others, have conspired to give Efut a very high GIDS ranking.

At present, the language is what we could describe as mortally moribund and extinct. It is virtually impossible to locate a fluent speaker of pure Nigerian origin. One bright prospect of Efut RLS lies in utilizing original Cameroonian Balondo speakers who now reside in Nigeria, as was done in our exploratory fieldwork. The remedial lessons in the language and on aspects of the tradition like libation, is heartwarming. The other ethnolinguistic aspect in retention that is ubiquitously exhibited is in Ekpe songs, despite the assimilating influence. Ekpe plays are highlighted proudly in the Annual Calabar Carnival with a nostalgic appreciation by diasporic Africans in attendance. This is a veritable source of foreign exchange earnings for Cross River State, evidence of the economic potential of indigenous language, culture.

Though some sources (e.g. Akak, 1998; Mensah \& Offiong, 2004) have emphasized that Efut is extinct, given the omnibus mortal symptoms, we are optimistic that with appropriate life-saving RLS options Efut would be revived. However, our optimism would only make sense if the Efut indigenes (first and foremost) and other critical stakeholders do not continue to sit on the fence. No language deserves to die given its enormous wealth and potentialities.

\section{References}

Akak, E. O. 1998. Efuts: Disintegration \& Integration: A chronicle of their sociological transformation from Efut to Efik [M]. Calabar: Ekikak Works.

Calabar in Wikipedia [OL]. http://en.wikipedia.org/w/index.php? Title=Calabar \& oldid=839729116.

Carney, S. 1936. Notes on the History of the Balondo Ba Mbenge [Z]. Ms. Mbonge.

Centre for Endangered Languages. 1997. Programme of Action on Endangered Languages [M]. Jos: Nigeria.

Connell, B. A. 1991. Phonetic Aspects of the Lower Cross languages and Their Implications for Sound Change [D]. PhD Dissertation. Edinburgh: University of Edinburgh.

Crozier, D. H. \& R. M. Blench (eds.). 1992. An Index of Nigerian Languages (2 ${ }^{\text {nd }}$ Edition) [M]. Dallas: Summer Institute of Linguistics.

Crystal, D. 1992. English as a Global Language [M]. Cambridge: Cambridge University Press. 
Cultural Dominance and Language Endangerment: The case of Efut in Cross River State, Nigeria

Crystal, D. 2000. Language Death [M]. Cambridge: Cambridge University Press.

Dixon, R. 1997. The Rise and Fall of Languages [M]. Cambridge: Cambridge University Press.

Edwards, V. \& T. J. Sienkewicz. 1990. Oral Cultures: Past and present [M]. Oxford: Blackwell Publishing.

Efut Combined Assembly. 2003. The Position of Efut Nation on Moves by Government to Achieve Unity, Peace and Stability in Calabar-Cross River State of Nigeria (Compiled) [Z]. Trabajo no publicado, Calabar.

Eisenlohr, P. 2004. Native Languages of the Americas: Endangered language revitalization and revival [J]. Annual Review of Anthropology, 33:21-45.

Ellis, P. B. 1985. The Celtic Language Revolution: A study in anti-imperialism [M]. Talybont: Y Lolfa.

Essien, O. E. 1979. Bilingualism in Nigerian Language among Primary School Children in Cross River State: A case study of the Mainland and Calabar Municipality [J]. Calabar Studies in Languages, 23:89-101.

Essien, O. E. 1982. Languages in the Cross River State [J]. Calabar Studies in Languages, 25:11-40.

Essien, O. E. 1987. Cross River State Languages: Problems and prospects [A]. In M. B. Abasiattai (ed.) Akwa Ibom and Cross River States: The land, the people and their culture [C]. Calabar: Wusen Press Ltd, 26-45.

Essien, O. E. 1990a. The Future of Minority Languages in Nigeria [A]. In Emenanjo (ed.). Minority Language, Multilingualism and Language Policy in Nigeria [C]. Agbor: Central Books Ltd, 155-168.

Essien, O. E. 1990b. Languages of the Upper Cross [A]. In S. O. Jaja, O. Erim \& B. W. Andah (eds.). History and Culture of the Upper Cross River State [C]. Enugu: Harris Publishers Ltd, 43-48.

Faraclas, N. 1989. Cross River [A]. In J. Bender-Samuel (ed.). The Niger Congo Languages [C]. Lanham: University Press of America, 377-339.

Fishman, J. A. 1991. Reversing Language Shift [M]. Clevedon: Multilingual Matters.

Fishman, J. A. (ed.). 2000. Can Threatened Languages Be Saved? [M]. Clevedon: Multilingual Matters.

Forde, C. D. \& G. I. Jones. 1950. The Ibo and Ibibio-speaking Peoples of South Eastern Nigeria [A]. In Daryll Forde (ed.). Ethnolinguistic Survey of Africa, Part III [C]. London: International African Institute, 67-94.

Hansford, K., J. Bendor-Samuel \& R. Standford. 1976. An Index of Nigerian Languages [A]. Studies in Nigerian Language [C]. Accra: Summer Institute of Linguistics, 5:1-20.

Haruna, A. 2009. Language Revitalization Programmes (NRP) in North-East Nigeria: Status, progress and challenges [A]. In E. A. Urua, M. Ekpenyong \& F. Ahoua (eds.). Language Development beyond Borders [C]. Ivory Coast: University of Uyo and University of Cocody, 51-74.

Kuperus, J. 1985. The Londo Word: Its phonological and morphological structure [M]. Tervuren: Koninklijk Museum voor Midden-Afrika.

Lambert, W. E. 1963. Psychological Approaches to the Study of Language Part I: On learning, thinking and human abilities [J]. Modern Language Journal, 14:51-62.

Lewis, P. 2009. Ethnologue: Languages of the world $\left(16^{\text {th }}\right.$ edn) $[\mathrm{M}]$. Dallas: Summer Institute of Linguistics.

McConvell, P. \& M. Florey. 2005. Language Shift, Code-Mixing and Variation [J]. Australian Journal of Linguistics, 25(1):1-7.

Mensah, E. O. \& O. A. Offiong. 2004. A Sociolinguistic Profile of the Calabar Urban [J]. Calabar Journal of Humanities, 4(2):24-36.

Miller, I. L. 2009. Voice of the Leopard: African secret societies and Cuba [M]. Jackson: The University Press of Mississippi.

Miller, I. L. 2012. Bongó Itá: Leopard society music and language in West Africa, Western Cuba and New York City [J]. Journal of Africa and Black Diaspora, 5(1):85-103.

Mougeon, R. \& E. Beniak. 1991. The Linguistic Consequences of Language Contact: The case of French in Ontario, Canada [M]. Oxford: Clarendon Press.

Ndimele, R. I. 2012. Language Policy and Minority Language Education in Nigeria: Cross River State educational experience [J]. Studies in Literature and Language, 4(3):8-14.

Nebengu, M. S. 1990. Origins and Settlement of the Balondo: A historical survey [D]. PhD Dissertation. 


\section{Margaret Mary Okon \& Paulinus Noah}

Cameroon: University of Yaounde.

Nigeria Conservation Foundation. 1997. Nigerian Endangered Species [M]. Lagos: NCF.

Nnadi, J. E. 1982. Baudelaire's "Greek Africans": A study of the influence of Hellenism on Baulaire's early conception of the African [J]. Calabar Studies in Languages, 24:14-26.

Noah, P. 1990. Kiong as an Endangered Language: Task for language engineers [R]. Paper presented at the Conference of the Linguistic Association of Nigeria. University of Calabar.

Noah, P. 1999. From Ethnic Marginalization to Linguistic Cleansing: A contribution to the national language question [A]. In G. O, Simire (ed.). Acts of the $19^{\text {th }}$ Modern Languages Association of Nigeria [C]. 87-100.

Noah, P. 2003. Education and Minority Language: The Nigerian dimension [A]. In O-M. Ndimele (ed.). Four Decades in the Study of Nigerian Languages: A festschrift for Kay Williamson [C]. Aba: NINLAN, 173-182.

Noah, P. 2004. An Outline of Efut Phonology: A study in endangered species [R]. Paper Presented at the 60 th Birthday Symposium of Okon Essien, May $27^{\text {th }}-28^{\text {th }}$, University of Calabar.

Okon M. M. 2004. The Kiong Language in the 21st Century: Problems and prospects [A]. In O. M. Ndimele (ed.). Language \& Culture in Nigeria: A festschrift for Okon Essien [C]. Aba: National Institute for Nigerian Languages, 91-96.

Okon, M. M. \& P. Noah. 2009. A Preliminary Report of Aspects of the Kiong Sound System [A]. In E. A. Urua, M. Ekpenyong \& F. Ahoua (eds.). Language Development beyond Borders [C]. Ivory Coast: University of Uyo and University of Cocody, 317-336.

Oku, E. E. 1989. The Kings and Chiefs of Old Calabar (1785-1925) [M]. Calabar: Glad Tidings Press.

Okwudishu, A. U. 1997. Endangered Languages and Communities: A call to action [A]. In A. U. Iwara (ed.). New Approaches to Literary and Linguistic Analysis [C]. 4:123-129.

Simmons, G. F. \& C. D. Finnig (eds.). 2017. Ethnologue: Languages of the world (20 ${ }^{\text {th }}$ edn.) [C]. Dallas: Summer Institute of Linguistics.

Sterk, J. P. 1979. A Tentative Classification of the Upper Cross Languages [J]. Calabar Studies in Languages, 2(3):74-88.

Tsunoda, T. 2006. Language Endangerment and Language Revitalization: An introduction [M]. Berlin: De Gruyter Mouton.

Udoh, I. I. \& B. A. Okon. 2008. The Languages of the Niger Delta Region of Nigeria [M]. Lagos: Concept Publications.

Udosen, E. E. 2009. Challenges of Language Documentation: The case of Borno State [A]. In E. A. Urua, M. Ekpenyong \& F. Ahoua (eds.). Language Development beyond Borders [C]. Ivory Coast: University of Uyo and University of Cocody, 37-49.

Ugot, M. \& M. N. Ogar. 2014. Language and Power in Cross River State, Nigeria [J]. Mediterranean Journal of Social Sciences, 5(10):648-656.

Vanguard Newspapers [N]. 2014. September 4.

Williamson, K. \& R. M. Blench. 2000. Niger-Congo [A]. In B. Heine \& D. Nurse (eds.). African Languages: An introduction [C]. Cambridge: Cambridge University Press, 11-42.

Yenda, H. B. 2009. Cultural Interaction among the Kaka People along the Nigerian/Cameroon Borderlands: 1801-1961 [D]. PhD Dissertation. University of Calabar. 